On 16 August 2018 accepted (subject to relatively minor corrections) for publication in Environmental Politics in 2019, volume 28, number 1.

\title{
Climate pioneership and leadership in structurally disadvantaged maritime port cities
}

Rüdiger K.W. Wurzel(a), Jeremy F.G. Moulton ${ }^{(a)}$, Winfried Osthorst $^{(b)}$, Linda Mederake $^{(c)}$, Pauline Deutz ${ }^{(a)}$ and Andrew E.G. Jonas ${ }^{(a)}$

University of Hull, UK ${ }^{(a)}$, University of Applied Sciences Bremen, Germany ${ }^{(b)}$, Free University of Berlin, Germany(c)

\begin{abstract}
This article assesses innovative climate governance in small-to-medium-sized structurally disadvantaged cities (SDCS) which have remained an under-researched subject area. Considering their deeply ingrained severe economic and social problems it would be reasonable to assume that SDCs act primarily as climate laggards or at best as followers. However, our novel empirical findings show that SDCs are capable of acting as climate pioneers. This article identifies and assesses different types and styles of climate leadership and pioneership and how they play out within multi-level and polycentric governance structures. It concludes that SDCS seem relatively readily willing to adopt transformational climate pioneership styles in the hope of creating 'green' jobs, for example, in the offshore wind energy sector and with the aim of improving their poor external image. However, in order to sustain transformational climate pioneership they often have to rely on support from 'higher' levels of governance. For SDCs there is a tension between learning from each other's best practice and fierce economic competition in climate innovation.
\end{abstract}

KEYWORDS Structurally disadvantaged cities, climate, pioneers, leaders, followers, offshore wind energy, green jobs, societal participation

\section{Introduction}

Research on climate leaders and pioneers was initially dominated by international relations (IR) and comparative politics (CP) scholars who focused mainly on climate governance at the international, supranational and state level (e.g. Rowlands 1995, Gupta and Grubb 2000). Initially, little scholarly attention was paid to climate leaders and pioneers at the sub-state level (e.g. regional, local and city levels) although there are exceptions, especially in the local governance literature (e.g. Bulkeley and Betsill 2005, While et al. 2010). Over time the 
importance of local climate governance increased to such a degree that Jänicke (2014, p. 43) has argued that 'the local level is a late mover in the process of climate policy, but has become the most dynamic driver of technical change towards a low-carbon energy system'.

The importance of local climate governance has increased for at least three reasons. First, IR and CP scholars discovered the significance of cities for global climate governance when the international climate negotiations threatened to end in political stalemate. Secondly, cities are both major sources of greenhouse gas emissions (GHGE) and laboratories for experimentation with innovative learning-by-doing climate governance measures, some of which could possibly be up-scaled from the local level to 'higher' governance levels (e.g. Bulkeley et al. 2015, Kemmerzell 2017, Kern, this Volume); thirdly, there is the issue of state 'hollowing out' where states are said to have lost power upwards (to the international and/or supranational level), sideways (to business and societal actors) and downwards (to the subnational level) (e.g. Strange 1998). Social scientists have tried to capture the purported move from top-down climate government towards bottom-up climate governance analytically with the help of multilevel governance (MLG) concepts (e.g. Schreurs and Tiberghien 2007, Wurzel et al. 2017) and polycentric governance approaches (e.g. Ostrom 2009, 2014, Morrison et al. 2017, Jordan et al. 2018) in which non-state and subnational actors play a prominent role. Urban politics scholars especially have argued that environmental governance is being rescaled around local and regional state structures in response to wider political and economic restructurings in liberal market economies (Bulkeley 2005, While et al. 2010). However, the state level continues to play an important role for many climate governance initiatives by SDCs which are not unitary actors. As will be explained below, local level societal climate alliances play an important role for the ability of SDCs to adopt innovative climate governance measures

Although there is growing interest in local climate governance, much of the literature has focused on relatively affluent and/or large cities that have acted as climate leaders or pioneers (e.g. Jonas et al. 2011, Bulkeley et al. 2015) and their national and transnational city networks (e.g. Kern and Bulkeley 2009). Little attention has been paid to innovative local climate governance by less affluent small-to-medium sized cities such as structurally disadvantaged cities (SDCs) which suffer from serious economic resource constraints (for exceptions see Bulkeley et al. 2015, Jonas et al. 2017). 
This article focuses on Bremerhaven (Germany) and Hull(1) (UK) as case study cities because both cities classify as SDCs which are faced with similar economic, social and geographic challenges. Moreover, Bremerhaven and Hull are maritime port cities that have perceived climate change as both a threat (e.g. flooding due to sea water level rise) and an opportunity (e.g. offshore wind energy jobs). Both Bremerhaven and, although to a lesser degree, Hull have experimented with innovative local climate governance measures. They have done so while acting primarily as pioneers as defined by Liefferink and Wurzel (2017), who have argued that leaders actively try to attract followers while this is not normally the case for pioneers (see also the Introduction by Wurzel et al., this Volume). Considering their acute resource constraints and other structural disadvantages it would seem reasonable to assume that SDCs act primarily as climate laggards or at best as followers. However, based on novel empirical findings put forward in this article we argue that this is not necessarily the case. Our article shows that SDCs are capable of acting as climate pioneers and, although to a lesser degree, leaders. This creates a research puzzle which we try to explain by answering the following main research question: How and why do SDCs act as climate pioneers or leaders?

This article proceeds as follows. In the next section we define SDCs before we briefly review the urban climate governance literature while linking it to the analytical concept of leaders and pioneers put forward by Liefferink and Wurzel (2017). Bremerhaven and Hull's main innovative local climate governance activities are then assessed. The penultimate section uses MLG and polycentric governance concepts to analyse the empirical findings from our two case study cities. The concluding section reassesses our conceptual framework and the main empirical findings while putting forward tentative general conclusions about small-to-medium sized SDCs that will require further research.

\section{Small-to-medium sized structurally disadvantaged cities}

For our definition of SDCs we draw on Jonas et al. (2017) who have defined structurally disadvantaged maritime port cities as suffering from: (1) geographical remoteness; (2) long term decline of industries (e.g. for maritime port cities fishing and shipbuilding); (3) disused industrial assets and infrastructure (e.g. port facilities); (4) high unemployment, low/underutilised skills base and declining populations; (5) weak economic governance structures (including shrinking tax bases and high susceptibility to austerity measures); and, 
(6) poor external image. Both Bremerhaven and Hull share these core characteristics of SDCs.

Our concept of SDCs resembles theories of structurally disadvantaged communities that have assessed minority communities in American inner cities, which exhibit serious social pathologies such as crime and public disorder (Kane 2005). Building on William Wilson's (1987) seminal book The Truly Disadvantaged, it is a phrase that seeks to capture the social and institutional structures (e.g. race and class) that have resulted in such communities becoming economically and socially marginalised. In our article, by way of contrast, we use the term SDCs in a more spatially and socially encompassing fashion to refer to small-to-medium sized cities that are grappling with a range of structural problems. In other words, our focus is not on a particular social subgroup within the city but rather a collective of small-to-medium sized cities that exhibit industrial decline, population loss, social problems, geographical peripherality and negative external images.

There is no hard and fast definition for what constitutes a medium-sized city. Le Galés (2002, p.5) has defined medium-sized cities as constituting of a population of between 150,000 and 200,000 inhabitants. However, Le Galés (2002, p. 32) also cites Kaelble (1988, p.62) who has pointed out that about one third of Europe's population has lived in ' $t$ t]he medium-sized town of between 20,000 and 100,000 inhabitants [which has] played a more significant and more enduring role in the twentieth century then elsewhere'. Small-tomedium sized cities cover free-standing urban centres having a population between 100,000 and 500,000; jurisdictionally, these are autonomous or separate local political jurisdictions governed by an elected city council or magistrate and led by a locally appointed or elected mayor; usually they are second or third tier urban centres within their host national economy/state. We have adopted the term small-to-medium sized city to take into account that Bremerhaven had a population of about 112,000 while Hull consisted of approximately 258,000 inhabitants in 2016 . The city of Bremerhaven together with the city of Bremen forms the state (Land) Bremen while Hull belongs to the Humber region, which have populations of about 672,000 and 921,000 respectively. For many years Bremerhaven has belonged to those German municipalities which suffer from the most severe economic problems (Wegweiser Kommune 2016). Röhl and Schröder (2017) have even concluded that Bremerhaven is the poorest German city in terms of purchasing power. In 2005 Bremerhaven suffered from an unemployment level of over 25\%. In 2016, Bremerhaven's 
unemployment rate still amounted to $14.6 \%$, which was more than twice the German national average although this constituted a slight improvement from 15.1\% (6.4\% national average) compared to 2015 (Statistisches Landesamt Bremen 2017). Decades of population decline were eventually reversed in the early 1990s. In 1968, Bremerhaven's population had peaked at about 149,000 before it bottomed out at about 108,000 in 2011. By 2016 Bremerhaven's population had grown again to about 116,000 , which was largely due to international immigration (Statistisches Landesamt Bremen 2017). Although Bremerhaven qualifies as a SDC, it nevertheless functions as a regional center for the labour market. In 2015, commuters constituted 47.3\% of regular employees in Bremerhaven (Bertelsmann Stiftung 2017). Commuters who work in Bremerhaven but are residents in the state Lower Saxony (Land Niedersachsen), which surrounds the cities of Bremerhaven and Bremen, do not pay taxes in the Land Bremen.

Hull's population declined for decades after it had peaked at around 302,000 in 1931 , falling to below 244,000 in 2001 . The 2011 census found the decline had moderately reversed, largely due to immigration (Migration Observatory 2014), although this trend could be reversed again following the UK's 2016 Brexit referendum in favour of leaving the European Union (EU). Hull's citizenry suffers from inter-generational unemployment, lack of skills development and social exclusion. In 2016, the city's unemployment rate was around 7.4\% as compared to $4.6 \%$ UK-wide which constituted a significant improvement compared to $13.5 \%$ (7\% national average) in 2015 (Hull Data Observatory 2017) ${ }^{(2)}$. A 2014 study of 64 UK cities, which compared indicators such as earnings, job seekers allowance and employment, ranked Hull amongst the most problematic cities (Centre for Cities 2014).

Table 1: Core features of Bremerhaven and Hull

\begin{tabular}{|c|c|c|}
\hline & Bremerhaven & Hull \\
\hline Inhabitants (2016) & $\begin{array}{l}\text { c. } 116,000 \text { (Land Bremen c. } \\
667,000)\end{array}$ & $\begin{array}{l}\text { c. } 258,000 \text { (Humber region c. } \\
921,000)\end{array}$ \\
\hline Unemployment (2015) & $15.1 \%$ (6.4\% national average) & $13.5 \%$ (7\% national average) \\
\hline Industrial decline & $\begin{array}{l}\text { Fishing industry, ship building, } \\
\text { departure of US army }\end{array}$ & Fishing industry, food industry \\
\hline Current major employers & $\begin{array}{l}\text { Offshore wind energy industry, } \\
\text { port, logistics, food industry, }\end{array}$ & $\begin{array}{l}\text { Chemical industry, port, } \\
\text { University of Hull, fledgling } \\
\text { offshore wind energy industry }\end{array}$ \\
\hline
\end{tabular}




\begin{tabular}{|l|l|l|}
\hline & $\begin{array}{l}\text { research (e.g. AWI), } \\
\text { Bremerhaven University }\end{array}$ & \\
\hline Offshore wind energy industry & $\begin{array}{l}\text { Adven/Areva and } \\
\text { Senvion/RePower as well as } \\
\text { WeserWind (until its } \\
\text { insolvency) and PowerBlades } \\
\text { (until it relocated) }\end{array}$ & Siemens, A2Sea \\
\hline $\begin{array}{l}\text { Research related to offshore } \\
\text { wind energy }\end{array}$ & $\begin{array}{l}\text { Fraunhofer Institute for Wind } \\
\text { Energy, Alfred-Wegener- } \\
\text { Institut, Hochschule } \\
\text { Bremerhaven }\end{array}$ & $\begin{array}{l}\text { University of Hull (e.g. aura } \\
\text { project), Hull College Energy } \\
\text { and Climate Centre }\end{array}$ \\
\hline $\begin{array}{l}\text { Direct jobs in offshore wind } \\
\text { energy industry }\end{array}$ & $\begin{array}{l}\text { c. 3,500 in 2014; c. 1,500 in } \\
2017 \text { (Germany: c. 20,000 in } \\
2017)\end{array}$ & $\begin{array}{l}\text { c. 1,000 in 2017 (c. 10,000 in } \\
\text { UK in 2017) }\end{array}$ \\
\hline Major flooding & $\begin{array}{l}1962,1999,2006,2016 \\
\text { 1953, 2007, 2013 }\end{array}$ \\
\hline
\end{tabular}

Sources: Jonas et al. 2017, Hull Data Observatory 2017 and Statistisches Landesamt Bremen 2017.

\section{Cities and climate pioneership and leadership}

'Cities lie at the heart of the challenge of addressing climate change' (Bulkeley et al. 2015, p.5) because they produce large amounts of GHGE and can act as laboratories for experimentation with innovative climate change measures. In the 1990s, innovative urban climate governance was largely driven by a limited number of relatively large and/or prosperous cities which acted as leaders or pioneers that formed national and/or transnational networks (e.g. Kern and Bulkeley 2009, Kern, this Volume). While largely ignoring SDCs early urban climate governance studies focused mainly on leading cities and their best practices, core indicators and success factors, studies have started to emphasise the increasing relevance of local climate governance for urban 'green' economic development.

Liefferink and Wurzel (2017) have argued that leaders usually actively seek to attract followers while this is not normally the case for pioneers. They furthermore distinguished between four types of leadership/pioneership - structural, entrepreneurial, cognitive, and exemplary - and two styles of leadership/pioneership, namely transactional and transformational (see also the Introduction by Wurzel et al., this Volume). However, their leadership/pioneership concept focused only on states while largely ignoring the subnational 
level. In this article we apply Liefferink and Wurzel's (2017) analytical environmental leader and pioneer concept to cities while focusing on SDCs.

In IR and CP structural leadership/pioneership is associated primarily with military and economic power. While military power does not play a significant role for tackling climate change, economic power capabilities are crucial at any governance level including the local level. In contrast to small-to-medium sized cities (e.g. Bremerhaven and Hull), large cities (e.g. Berlin and London) have considerable economic power and thus structural leadership/pioneership capabilities. However, as Burns (1978, p. 19) has pointed out '[a]II leaders are actual or potential power holders, but not all power holders are leaders'. Cities' formal institutional powers can be interpreted as representing structural power resources. For example, city states (Stadtstaaten) such as Bremen, which encompasses the cities of Bremerhaven and Bremen, have significant powers under the German federal constitution. Structural leadership/pioneership activities may also include economic actions which are aimed at improving cities' positions in urban hierarchies or vis-à-vis cities with similar 'green' economy ambitions.

Entrepreneurial leadership/pioneership involves the use of diplomatic and negotiating skills with a view to brokering integrative bargains and agreements. Entrepreneurial leadership also includes networking between actors, sectors and governance levels. As explained below, for an emerging new industrial sector like the offshore wind industry entrepreneurial leadership in the form of networking is of central importance. MLG concepts have tried to capture analytically such networks and their interdependencies across different governance levels. While emphasising the importance of local entrepreneurial initiatives, experimentation and learning-by-doing, polycentric climate governance concepts (e.g. Ostrom 2009, 2014) have stressed the significance of selforganisation, trust building and site-specific conditions (e.g. Dorsch and Flachsland 2017, Morrison et al. 2017; Jordan et al. 2018).

Cognitive leadership/pioneership involves defining and redefining interests and developing innovative ideas such as the 'green economy' or low carbon economy which aim to generate 'green' jobs while reducing GHGE. Cognitive leadership/pioneership may conceptualise climate change not only as a threat but also as an opportunity. It may also relate to branding/rebranding strategies with the aim of improving the external image of SDCs (e.g. from climate laggard to leader or pioneer), which try to attract inward investment 
and skilled people to the city. Such rebranding goes well beyond superficial 'greenwashing' or symbolic climate leadership/pioneership if it is supported by significant GHGE reductions. The urban governance literature has emphasised the importance of cities and regions as laboratories for experimentation and innovation (e.g. Bulkeley and Betsill 2005, Ostrom 2009) although little is known about whether SDCs can fulfill similar functions.

Finally, exemplary leadership/pioneership refers to the setting of examples for others either intentionally or unintentionally. Intentional exemplary leaders put forward climate governance measures as models for others. Unintentional example setting, in contrast, refers to pioneers who do not intentionally aim to attract followers (see the Introduction by Wurzel et al., this Volume). Cities that adopt the Covenant of Majors usually try to set a good example, which they would like others to follow (e.g. Bulkeley et al. 2015). Such cities therefore act as climate leaders. However, innovative urban climate governance measures may also be adopted without the intention of setting an example for other cities thus amounting to climate pioneership rather than leadership.

Liefferink and Wurzel (2017) differentiate between internal and external ambitions while arguing that an actor with high internal and low external ambitions acts as a pioneer, which has no explicit intention to attract followers (see also the Introduction by Wurzel et al., this Volume). We argue that SDCs may well have high internal climate ambitions which, however, they do not normally use to attract followers. In our article the term pioneership therefore refers to internal climate ambitions of SDCs (rather than their external ambitions which would amount to leadership).

These four different types of leadership/pioneership can be combined analytically with the following two leadership/pioneership styles, namely transactional and transformational (Liefferink and Wurzel 2017). Transactional leadership/pioneership refers to incremental changes usually over a relatively short time horizon while transformational leadership/pioneership aims at profound or even 'revolutionary' changes usually over a comparatively long time period. Transactional climate leadership/pioneership resembles efforts to make cities more resilient to climate change although such efforts can lead to a 'resilience trap' (Kythreotis and Bristow 2017) which merely reinforces the status quo. However, transactional leadership/pioneership extending over a very long timescale may eventually also trigger transformational change (e.g. Burns, 1978). 


\section{Climate governance in structurally disadvantaged cities}

\section{Urban climate strategy}

In Bremerhaven local climate governance experienced a substantial boost and institutionalisation with the approval of the Climate City (Klimastadt) concept in 2010. Its adoption followed a motion in the city parliament (Bremerhavener Stadtverordnetenversammlung) in 2007 and the publication of a conceptual study in 2009 (AWI 2009). The full name of the Klimastadt is Kurs Klimastadt, which translates into English as 'on course to becoming a climate city' and 'resonates well with the maritime image of Bremerhaven' (Interview, 2016). As one climate city office (Klimastadtbüro) staff emphasised: 'We are not yet a climate city. We are on course to becoming one' (Interview, 2016). As will be explained below, Bremerhaven's climate city concept identified not only municipal steering and monitoring instruments but also proposed the creation of an innovative green economy cluster which until the mid-2010s focused almost exclusively on the offshore wind energy industry.

In 2006, Bremerhaven followed Bremen's lead by applying for the European Energy Award (EEA) certification scheme to establish a monitoring and implementation tool for climate management. Five years later, Bremerhaven achieved the scheme's requirements and obtained the EEA award for the first time. In 2007, Bremerhaven prepared a research and development concept with the aim of transforming the existing network of climaterelated institutions into a flagship project while trying to exploit its full economic potential. The concept focused on the following three 'climate lighthouses' (Klimaleuchttürme): (1) regional business promotion in the offshore wind energy sector; (2) top-level, climaterelated research activities; and, (3) tourist attractions such as the climate house (Klimahaus) museum (Mederake 2015). Initiated by a Christian Democratic Union (Christlich Demokratische Union - CDU) and Social Democratic Party (Sozialdemokratische Partei Deutschlands - SPD) local government coalition in 2008, Bremerhaven City Council adopted a Master Plan Active Climate Policy as strategic frame for local state and non-state climate measures.

In 2010 Bremerhaven launched the climate city Bremerhaven (Klimastadt Bremerhaven) initiative with the aim of improving its poor external image, strengthening its climate-related capacities, boosting jobs in the offshore wind energy sector and reducing GHGE. At the centre of the climate city project was the attempt to raise Bremerhaven's 
internal climate ambitions with the aim of changing its negative image in order to attract external investment. Bremerhaven adopted important infrastructure measures while providing advice to potential investors through the Bremerhaven Economic Development Company and City Development (Bremerhavener Gesellschaft für Investititionsförderung und Stadtentwicklung- BIS), which increased its staff and knowledge resources on offshore wind energy. Bremerhaven thus positioned itself as a climate pioneer while offering especially entrepreneurial and cognitive pioneership. With the adoption of its climate city project Bremerhaven opted for a transformative pioneership style, which was aimed at mitigating climate change while transforming the city's economic fortunes with the help of the offshore wind energy industry.

Following local elections for Bremerhaven's City Council in 2011, the CDU-SPD coalition was replaced by a 'Red-Green' coalition government made up of the SPD and the Green Party. The 2011 local elections had taken place shortly after the Fukushima nuclear catastrophe, which greatly boosted the electoral support for the Green Party that headed (among other posts) the Environmental Councillor (Umweltdezernentin). At the request of the Greens, the focus of the Klimastadt project was widened from a relatively narrow focus on in particular 'green' business activities (i.e. the offshore wind energy sector) to include also public participation initiatives with civil society actors. Largely on the insistence of the new Green Environmental Councillor the climate city office (Klimastadtbüro), which had been set up in 2014, was moved to new premises in a prime location in the city centre where it opened its doors for the general public in 2015. However, the need for budget cuts and changed political priorities of the newly elected CDU-SPD government in Bremerhaven triggered a moderate reduction in staff and the Klimastadtbüro's relocation to cheaper, more remote premises in 2017.

Bremerhaven's local climate governance targets became more ambitious as a consequence of programmes developed by the Land Bremen, which has been governed by a SPD-Green coalition government since 2007. The Land Bremen adopted the Climate Protection and Energy Policy Programme 2020 (Klimaschutz- und Energieprogramm 2020 KEP 2020) for Bremen and Bremerhaven in 2010 (SUBV 2010). The KEP set an ambitious $40 \%$ reduction target for $\mathrm{CO}_{2}$ by 2020 (compared to 1990). As a consequence, Bremerhaven also committed itself to reducing $\mathrm{CO}_{2}$ emission by $40 \%$ by 2020 . In 2015 , these reduction 
targets were strengthened when they were included in the Bremen State Climate and Energy Act (Bremisches Klimaschutz- und Energiegesetz).

Hull's Environment \& Climate Change Strategy 2010-2020, which was published in 2010, also set ambitious $\mathrm{CO}_{2}$ emissions reduction goals. Hull's 2010 Strategy took note of the EU's legally binding 20\% and the UK's 32\% reduction goals for 2020 and adopted the somewhat more ambitious reduction goal of $34 \% \mathrm{CO}_{2}$ emissions by 2020 with a $45 \%$ ambition goal for 2020 (Hull City Council 2010). Since the publication of the 2010 Strategy, UK local government has been affected by austerity-driven funding cuts imposed by central government. These cuts have had an adverse effect on the willingness and ability of Councils to fund climate action (Buranyi 2016) and their ability to offer climate pioneership. However, funding cuts have promoted independent power generation from renewable sources and energy efficiency measures to save money.

Since 2011, Hull Council has regularly reviewed its $\mathrm{CO}_{2}$ emissions and published annual reports. Efforts to reduce emissions include the deployment of photovoltaic units on Council buildings. City street lighting has begun to be replaced with LED bulbs to reduce energy usage and cost. Hull City Council partnered with 'green economy' and third sector actors to create the Green City Group in 2011. The Group was established in order to consider the branding of Hull as a Green City, in a similar but coincidental manner to Bremerhaven's Klimastadt project. Ultimately, with the adoption of Hull's City Plan the decision was made to market the city instead as Energy City (Hull City Council 2013). Whilst this represented an ideational shift away from outright climate pioneership to an economic marketing strategy, the City Council has nevertheless demonstrated some local climate pioneership. Unlike in Bremerhaven, one political party (Labour) has consistently dominated post-Second World War local politics in Hull, with the exception of 2007-11 when the Liberal Democrat Party held the majority in Hull City Council. Other political parties such as the Green Party and the United Kingdom Independence Party (UKIP) have had little influence in local government.

Especially when considering the vulnerability of maritime port cities to climate change (e.g. sea water level rise) and the resource constraints which SDCs suffer from, it is perhaps surprising that Bremerhaven and Hull adopted a significant number of climate mitigation initiatives instead of solely supporting adaptation activities which are beyond the scope of this article. 
Post-Second World War Bremerhaven has suffered from significant flooding events in 1962, 1999, 2006 and 2016 while Hull has been affected by major flooding in 1953, 2007 and 2013 (see Table 2). Recent serious flooding events have helped local officials in both cities to push climate change higher up on the local government agenda (Interviews, 20142017). As one City Council official stated, the flooding has been key in developing the city's climate actorness: 'From the experience in 2007 with the floods there and the 2013 tidal surge, we're a lot further ahead than a lot of cities'.

Table 2: Climate governance innovations in Bremerhaven and Hull

\begin{tabular}{|c|c|c|}
\hline & Bremerhaven & Hull \\
\hline \multicolumn{3}{|c|}{ 1. Urban climate strategy } \\
\hline $\begin{array}{l}\text { Strategic } \\
\text { manage- } \\
\text { ment }\end{array}$ & $\begin{array}{l}\text { - } 2008 \text { MAK, updated } 2011 \\
\text { - } 2010 \text { KEP: }-40 \% \mathrm{CO}_{2} \text { by } 2020 \\
\text { - } \text { Bremen State Law on Climate Protection } \\
\text { and Energy: }-40 \% \mathrm{CO}_{2} \text { by } 2020 \\
\text { - } \text { EEA since } 2006 \\
\text { - Environment Protection Agency: one } \\
\text { official for climate and the Climate City } \\
\text { Office since } 2014\end{array}$ & $\begin{array}{l}\text { - Environment and climate change } \\
\text { strategy 2010-2012: -34\% CO } 2 \text { by 2020; } \\
\text { ambition: }-45 \% \\
\text { - Green City Group (2011-2012) } \\
\text { - Councillor with Energy City portfolio } \\
\text { - One Council official responsible for } \\
\text { environment/climate }\end{array}$ \\
\hline $\begin{array}{l}\text { Societal } \\
\text { participation }\end{array}$ & $\begin{array}{l}\text { - Six Climate City working groups } \\
\text { - Youth Climate Council } \\
\text { - Climate City Day since } 2013 \\
\text { - Urban climate policy participatory dialogue } \\
\text { (2012) } \\
\text { - Climate change education at schools }\end{array}$ & $\begin{array}{l}\text { - Goodwin Development Trust's climate- } \\
\text { themed artist residencies and } \\
\text { community engagement projects }\end{array}$ \\
\hline Rebranding & $\begin{array}{l}\text { - } \quad \text { Climate City concept since } 2009 \\
\text { - } \quad \text { Odyssee Climate event (2013) } \\
\text { - } \quad \text { Electric cars rally (2016) }\end{array}$ & $\begin{array}{l}\text { - Energy City concept } \\
\text { - Humber region as 'Energy Estuary' } \\
\text { - } 2017 \text { City of Culture climate-themed } \\
\text { events }\end{array}$ \\
\hline \multicolumn{3}{|c|}{ 2. Green economy } \\
\hline $\begin{array}{l}\text { Offshore } \\
\text { Wind Energy }\end{array}$ & $\begin{array}{l}\text { - Offshore wind energy cluster: peak of } \\
\text { c.3,500 jobs in 2014; declined to 1,500 in } \\
2017 \\
\text { - } \\
\text { Research institutes (e.g. Alfred-Wegener- } \\
\text { Institut, Fraunhofer Institute for Wind } \\
\text { Energy Systems) } \\
\text { - Training and research at Hochschule } \\
\text { Bremerhaven } \\
\text { - WAB } \\
\text { - } \text { BIS } \\
\text { - OTB plans stalled }\end{array}$ & $\begin{array}{l}\text { - Green Port Hull: c. 2,000 jobs in 2017; } \\
\text { moderate increase expected) } \\
\text { - Siemens c. 1,000 jobs in } 2017 \\
\text { - Specialised training (e.g. Humber } \\
\text { Onshore \& Offshore Training } \\
\text { Association) } \\
\text { - Training and research at Hull University } \\
\text { (e.g. project aura) }\end{array}$ \\
\hline
\end{tabular}

\section{Societal participation strategies}

Bremerhaven's Klimastadt programme set up working groups in which local government, civil society, and business actors cooperate on (1) economy/science, (2) citizens and 
education, (3) construction and modernisation of buildings, (4) communication, (5) mobility, and (6) sustainable tourism. Additional innovative participatory elements in the Klimastadt project included an annual festival-like climate day (Klimatag) and, since 2014, a Youth Climate Council (Jugendklimarat) which has a small budget and the right to speak in the City's Environmental and Construction Committee. In 2013, the Klimastadt funded the transdisciplinary festival Odyssee Klima (Odyssey climate) in which Bremerhaven's city theatre (Stadttheater) took on a leading role. The festival featured climate change related plays and performances by actors and scientists in Bremerhaven's city centre and in wind turbine production factories (Interviews, 2014-17).

Hull's status as the UK's City of Culture in 2017 has involved few climate-related activities. When compared to Bremerhaven, societal participation has remained underdeveloped in Hull's climate governance strategy. Hull's adoption of the Energy City brand is mainly aimed at business and 'green economy' actors rather than at societal actors. However, Hull's status as the UK's City of Culture in 2017 has been used, albeit hesitantly, for raising public attention to climate change related issues (Interview, 2016). One example constitutes 'The Blade' installation which involved exhibiting a 75-metre rotor blade of an offshore wind turbine in the city centre in early 2017. Another example was an exhibition entitled 'Somewhere becoming Sea' which focused on the ever-changing boundaries between land and sea while trying to capture 'the sea's elemental power ...[a]t a time when climate change threatens to blur boundaries further and bring far-reaching economic impact' (Hull UK City of Culture, 2017).

\section{The green economy}

In Bremerhaven, the Land Bremen and the city of Bremerhaven identified the offshore wind energy industry and, although to a much lesser degree, the onshore wind energy industry as potential major growth sectors in 2003. This occurred against the background of ambitious national renewable energy targets, generous subsidies for renewable energy and the decision to phase out nuclear power in Germany. There was a concerted attempt to turn easy access to the Sea, disused industrial facilities (e.g. from shipyards) and derelict land together with underutilised maritime-related job skills into an advantage. Substantial investment and various state and city agencies (including the BIS) facilitated the creation of an offshore wind energy cluster in Bremerhaven. Highly regarded, nationally funded 
research facilities such as the Alfred-Wegener-Institut (AWI) and Fraunhofer Institute for Wind Energy and Energy System Technology (IWES) moved to Bremerhaven in 1980 and 2009 respectively. Sectoral associations and specialised networks for the offshore wind energy sector (e.g. the wind energy agency Bremerhaven (Windenergie Agentur Bremerhaven - WAB)) were also set up. The WAB became an important network, which provided entrepreneurial pioneership in the form of networking opportunities for the fledgling offshore wind energy industry in Bremerhaven and the wider region. Specialised academic training programmes were offered by the University of Applied Sciences Bremerhaven (Hochschule Bremerhaven) thus strengthening Bremerhaven's cognitive pioneership capacities. In short, the local government in Bremerhaven tried to create, with the support of in particular businesses, entrepreneurial and cognitive pioneership capacities for the offshore wind energy industry. Its structural pioneership capacities relied primarily on economic support from the Land Bremen and/or federal government funds.

In 2014, the offshore wind energy industry reached a peak with around 3,500 jobs in Bremerhaven (Written communication, BIS, 2017). The joint efforts of the city Bremerhaven and the Land Bremen led to the establishment of a leading offshore renewable energy industry cluster that included companies such as Adven (formerly called Areva) and Senvion (previously RePower) as well as WeserWind, which became insolvent in 2015, and PowerBlades which decided to closed its factory in Bremerhaven in 2018. It could be argued that the concerted action by Bremerhaven in cooperation with the Land Bremen amounted to local government structural leadership with the aim of transforming the socio-economic structure of the city.

As a result of the boom of the offshore wind energy industry, plans for an Offshore Terminal Bremerhaven (OTB) at an estimated cost of $€ 180$ million were put forward in 2010. However, they were halted at least temporarily when the environmental NGO BUND (Friends of the Earth Germany), took legal action against its construction while arguing that the OTB was no longer economically viable. As a consequence of reforms to the German Renewable Energy Law (Erneuerbare-Energies Gesetz - EEG) in 2014 and 2016, funding for offshore wind energy production decreased significantly. The federal government also adopted a two-year moratorium for the expansion of offshore wind farms in the North Sea while government funding was diverted for political reasons to offshore wind farms in the Baltic Sea, which economically benefit the Northern coastal state in the former East 
Germany. The combination of these measures significantly dampened hopes for ambitious expansion plans for Bremerhaven's offshore wind energy capacity. The number of direct and indirect jobs in the offshore wind energy sector in Bremerhaven, which had peaked at approximately 3,500 in early 2014, fell to about 1,500 staff in 2017 (Written communication, BIS, 2017). The main reason for this steep decline was that WeserWind, which had employed approximately 1,200 staff in 2012-2013, went bankrupt in early 2015 . In the same year Siemens, which is one of Europe's leading offshore wind turbine producers, invested in a new factory in neighbouring Cuxhaven while its wind turbine production facilities across the North Sea in Hull became operational in early 2017. Moreover Powerblades, which had a staff of about 300 in Bremerhaven in 2017, announced plans to relocate its plant in early 2018. Consequently, Bremerhaven has tried to broaden its relatively narrow focus on the offshore wind energy industry towards a wider focus on the green economy (Interviews, 2017).

Hull's climate pioneership is mainly the result of the adoption of green economy measures and a municipal drive towards climate change mitigation and adaptation. Compared to Bremerhaven, Hull's adoption of climate governance measures can be described as more hesitant. Whilst Hull exhibited climate pioneership somewhat later than Bremerhaven, its green economy measures have been less narrowly focused on the offshore wind energy sector while including also other forms of renewable energy such as biomass. Hull has become a centre for the biofuel industry, which is however not without its environmental critics (e.g. Mol 2010). Associated British Ports (ABP) along with the Spencer Group, a Hull-based engineering company, developed a biomass terminal and storage facility for fuel for the former coal-fired Drax power plant (in North Yorkshire). Within Hull itself, Vivergo Biofuels, a co-venture by BP, AP Sugar, and DuPont, was the largest biorefinery in the UK at the time it opened.

Despite the decline of the fishing industry, a section of Hull's port-based industry stayed active. The ports act both as cargo and ferry terminals. However, the gap left by the decline of the city's primary industry led to the recognition that a new major industry was needed to give the city 'a renewed raison d'etre' (Interview, 2016). It is into this gap that the green economy has been ushered. Here 'gap' refers to both an economic and physical space which made Hull an attractive site for Siemens when considering the placement of a new blade manufacturing and offshore wind turbine assembly facility. As well as the brownfield 
and quay space in Hull, the city's location close to important UK offshore wind farm sites, made it a particularly suitable development location (Jonas et al. 2017). Hull City Council, local MPs and national politicians were able to secure the Siemens facility in Hull as part of a £310 million joint venture with ABP which manages four important regional ports: Hull, Goole, Grimsby, and Immingham. The Siemens-ABP facility was opened in early 2017. From initial plans to produce 450 blades a year, Siemens has increased its intended yearly output to 600 blades for deployment in 6MW turbines in UK waters and further afield. However, the UK's decision to leave the EU has put into question Siemens' future ability to use its Hull production site for exports to the EU. By 2017 the site created 1,000 direct jobs, 95\% of which were filled by people from the region. The Siemens-ABP Green Port Hull development is Hull's most high-profile green economy development, but there are also other local green economy projects.

Spurred on by the achievement of attracting Siemens to Hull, local economic development practitioners have seen an opportunity to address the city and region's longstanding structural disadvantages. In other words, local governance actors have tried to adopt a transformative pioneership style. In 2013, Hull approved a 10-year City Plan to attract $£ 1$ bn in investment and create up to 8,000 new jobs for local job seekers over the next 10 years (Hull City Plan, 2017). A central component of the City Plan was Energy City, an umbrella term for flagship industry projects - the majority of which can be classed as part of the green economy. A key driver in Hull's proposed economic transformation has been the Humber Local Enterprise Partnership (LEP). In 2013, LEPs replaced Regional Development Agencies as private sector led economic development organisations, albeit ones retaining significant public sector representation. In its Strategic Economic Plan, the Humber LEP recognised that addressing climate change is essential to the competitiveness of Hull because of the need for building inward investor confidence and reducing flooding risk. Nevertheless, although the LEP has recognised the wider social and environmental benefits of climate adaption, its priority is to support mainstream economic development, including 'green' jobs. LEP's main goal is to put 'the Humber [at] the centre of renewable energy [in the UK] - so that when people think of energy they will think of the Humber' (Interview, Hull, 2014).

The evolution of the renewables sector in Hull demonstrates the city's belated structural pioneership. Hull's status as a belated pioneer could possibly turn out to have 
been an advantage. The city has become a home to an established, market-dominant player in Siemens. If Hull had pushed for such an offshore wind production base earlier, it possibly would have been harder to find such an established partner. The insolvency of WeserWind and the relocation of Powerblades in Bremerhaven as well as Siemens' investment in neighbouring Cuxhaven illustrate the risk which structural local climate pioneership poses for SDCs. The 'first mover' advantage, which has been identified for states and companies (e.g. Porter 1990) may possibly play out differently at the city level at least for SDCs. Hull closely followed Bremerhaven's exemplary pioneership. By sending delegations to Bremerhaven, Hull tried to learn lessons from one of Europe's offshore wind energy pioneers. However, lesson drawing quickly turned into competition for investment - as Bremerhaven was also a city considered for the Siemens plant now housed in Hull. This shows that there is thin dividing line between learning from best practice generated by local climate experimentation and fierce economic competition between SDCs which want to attract investment from transnational corporations (see also Kemmerzell 2017).

\section{Explaining urban climate governance in SDCs: multi-level, polycentric or place-specific?} MLG concepts have emphasised the mutual dependency of governance actors at different governance levels (e.g. EU and subnational levels). In contrast, polycentric governance concepts attribute usually a higher degree of autonomy to subnational actors (e.g. cities and regions) and societal actors (e.g. business, NGOs and individual citizens) as regards experimentation with innovative local climate governance measures and learning-by-doing. Put simply, while MLG concepts tend to focus on the globalization (or 'glocalisation') and, within the European political context, the Europeanisation of regional and local actors (e.g. Hooghe 1996), polycentric governance concepts stress the crucial role that local climate governance experiments play for the success of global climate governance regimes (e.g. Ostrom 2009).

Polycentric governance concepts share certain core presuppositions (e.g. multiple centres of authority and levels of governance) with MLG approaches, although conceptually they are not identical (e.g. Homsy and Warner 2014, Wurzel et al. 2017, Jordan et al. 2018). By comparison with MLG approaches, polycentric concepts normally assume a stronger role for societal actors and attribute a high degree of autonomy to both subnational actors (e.g. cities) and non-governmental societal actors (Ostrom 2009, 2014). Polycentric governance 
approaches usually emphasise the importance of bottom-up local governance mechanisms and argue that local climate governance ought to supplement, if not partly supplant, global climate governance initiatives. Broadly speaking, it could be argued that proponents of polycentricity favour societal self-coordination within market-like governance structures (e.g. Ostrom, 2014, for a critical review see Morrison et al. 2017) while MLG advocates support the creation of networks in which governmental actors (including supranational EU actors) play an important, if not dominant, role, e.g. to correct negative market externalities (Hooghe 1996; Homsy and Warner 2014).

Proponents of polycentricity usually argue in favour of a multitude of decisionmaking 'centres' and widespread subnational societal self-coordination in climate governance (e.g. Ostrom 2009, 2014). From a polycentric perspective one would normally expect smaller and more independent cities to exhibit greater degrees of climate leadership/pioneership. At first sight the empirical findings presented above might suggest that it is 'game, set and match' for polycentric governance perspectives as Bremerhaven, which has exhibited a higher degree of climate innovation, is smaller and enjoys a greater degree of local governance independence compared to Hull. However, our empirical findings also show Bremerhaven's high dependency (especially for structural climate pioneership) on decisions that were taken on the national governance level. Prominent examples are the reforms of the EEG and its detrimental impact on the offshore wind energy industry in Bremerhaven. Our findings therefore emphasise the importance of MLG structures and relevance of MLG concepts.

Both Bremerhaven and Hull took account of national and $\mathrm{EU} \mathrm{CO}_{2}$ reduction targets when setting their local reduction targets (see Table 3). As explained above, for Bremerhaven the $\mathrm{CO}_{2}$ reduction targets of the Land Bremen were also of crucial importance while for Hull no such additional layer of local climate governance existed.

Table 3: Multilevel climate governance context

\begin{tabular}{|l|l|l|l|l|l|}
\hline & EU & Germany & Bremerhaven & UK & Hull \\
\hline $\begin{array}{l}\mathrm{CO}_{2} \\
\text { emission } \\
\text { reduction }\end{array}$ & $2012:-8 \%$ & $2012:-21 \%$ & & $2012:-12.5 \%$ & \\
$\begin{array}{l}\text { (1990 } \\
\text { baseline) }\end{array}$ & $2020:-20 \%$ & $2020:-40 \%$ & $2020:-40 \%$ & $2020:-32 \%$ & $2020:-34 \%$ \\
& & $2030:-55 \%$ & $2030:-50 \%$ & & \\
\hline
\end{tabular}




\begin{tabular}{|l|l|l|l|l|l|}
\hline & $2050:-80-95 \%$ & $2050:-80-95 \%$ & $2050:-80 \%$ & $2050:-80 \%$ & $2050:-80 \%$ \\
\hline
\end{tabular}

\section{Conclusion}

This article has assessed how small-to-medium sized SDCs (e.g. Bremerhaven and Hull) have responded to climate change by developing climate pioneership capacities at the urban level. Based on our empirical evidence it seems safe to state that Bremerhaven exhibited a higher degree of experimentation and innovation in local climate governance than Hull which focused more on the mainstreaming of innovative local climate action within economic development, with the latter remaining dominant. Bremerhaven's climate city (Klimastadt) concept clearly goes well beyond Hull's Energy City concept in terms of local climate governance innovation. While offering exemplary pioneership Bremerhaven has adopted more ambitious long-term $\mathrm{CO}_{2}$ reduction goals than Hull, which acted as a follower in relation to Bremerhaven also in terms of creating offshore wind energy industry capacities at a later stage. However, there are concerns about Bremerhaven's ability to maintain such climate pioneership over a long time period, which is usually required to produce transformative effects, without additional support from a 'higher' governance level (e.g. the Land Bremen, federal government and/or EU). The long-term success of Bremerhaven's transformative pioneership may also require a certain degree of modification, which is not unusual for learning-by-doing local climate experiments and innovation. For example, Bremerhaven's initial narrow focus on the offshore wind energy sector as a transformative industrial sector had to be broadened to encompass the wider green economy following significant changes at the national governance level (e.g. the reforms of the EEG) which had a detrimental effect on the offshore wind energy industry in Bremerhaven.

As our article has focused only on two case study cities, we are able to draw only tentative general conclusions about innovative climate governance in SDCs, which have remained under-researched. Additional further research will be needed to show whether our empirical findings are indeed representative for SDCs. Such research ought also to assess critically whether the use of the pioneer and leader concept indeed adds analytical value to assessing critically local climate governance. With this in mind, we put forward the following five main conclusions. 
First, considering their structural disadvantages it would be reasonable to assume that SDCs act primarily as climate laggards or at best as followers. However, our empirical research has clearly shown that SDCs do not necessarily act as climate laggards. Instead they can become climate pioneers or at least followers.

Secondly, SDCs seem to conceptualise climate change not only as a threat (e.g. flooding) but also as an opportunity (e.g. 'green' jobs). To be able to exploit such opportunities, SDCs have to create cognitive and entrepreneurial pioneership capabilities which require the involvement of local governance actors, businesses, NGOs and citizens. However, for the creation of considerable structural pioneership capacities, SDCs are significantly more reliant on (e.g. financial) support from 'higher' levels of governance such as regional and national governments or the EU (see also Morrison et al. 2017).

Thirdly, arguably because of their deep-rooted economic and social problems, SDCs seem relatively willing to endorse transformational climate pioneership styles in the hope of turning their economic fortunes around and improving their poor external image. However, a long term transformational climate pioneership style is contingent on being compatible with core local economic goals, strong support from local governance actors (including local officials, political parties, businesses and societal actors) and at least some support from 'higher' levels of governance.

Fourthly, for SDCs there is a tension between learning from each other's best practice in terms of local climate experiments and innovation, and fierce economic competition for inward investment for 'green' jobs (e.g. in the offshore wind energy sector).

Fifthly, it could be argued that Liefferink and Wurzel's (2017) claim that environmental pioneers and leaders are either 'first in class' or 'best in class' applies to SDCS (e.g. Bremerhaven and Hull) only to the degree that these two cities are more often than not able to show pioneership in their particular place in the urban system, namely structurally disadvantaged maritime port cities. Comparing Bremerhaven and Hull with cities other than SDCs would therefore be akin to comparing apples with oranges in the English idiom. This poses an analytical challenge for the state-focused leader and pioneer typology as put forward by Liefferink and Wurzel (2017) because there are arguably more different types of cities than there are different types of states. The applicability of different leadership types - structural, entrepreneurial, cognitive and exemplary - is challenging for assessing urban climate governance although it can add analytical value. Focusing on 
different types of pioneership (and leadership) creates greater analytical awareness of the fact that SDCs may, for example, try to attract renewable energy industry (structural leadership), build extensive networks and new climate alliances within the city as well as across different governance levels (entrepreneurial leadership) and conceptualise climate change not only as a threat but also as an opportunity when attempting to rebrand the city with the help of innovative local climate innovations (cognitive leadership).

Place clearly makes a difference to how analytical concepts (such as the pioneership/leadership concept) can be used to assess local climate governance actions within MLG and polycentric governance structures. The need to make concepts placespecific suggests the importance of contextual factors, which may differ significantly even for the same or similar types of cities such as small-to-medium sized SDCs. As Le Galés (2002, p.268) has pointed out: 'Each city represents something unique [which is] the result of a unique history'. There are therefore certain path-dependencies, which SDCs with limited resources will find difficult to alter radically. Perhaps the key message is that the analysis of climate change policy in SDCs can be helpful in demonstrating how concepts of environmental leadership which were originally designed for international and national comparisons can also be applied to the urban scale. In addition, as much as it sheds light on large-scale trends towards multi-level and polycentric climate governance, urban comparative analysis also helps to expose differences in how climate leadership plays out at the urban scale. Clearly additional research on climate governance in SDCs is needed to allow for more robust generalisable conclusions.

\section{Acknowledgements}

Rudi Wurzel and Andrew Jonas are grateful to the British Academy (grant no. SG 131240) and the University of Hull for funding. The authors would like to thank their interviewees. More than 70 interviews with local politicians, officials, businesses and NGOs were undertaken. Most interviews took place in Bremerhaven and Hull while two were carried out in Berlin and Dessau in 2014-17. We are grateful to the referees for their very helpful comments. An earlier version of this manuscript was delivered at the Innovations in Climate Governance (INOGOV) funded workshop on 'Pioneers and Leaders in Polycentric Climate Governance (PiLePoC) in Hull on 15-16 September 2016. The usual disclaimer applies. 


\section{Disclosure statement}

No potential conflict of interest was reported by the authors.

\section{Endnotes:}

(1) Hull is formally called Kingston-upon-Hull although it is widely referred to as Hull (see: http://www.hullhistorycentre.org.uk/discover/hull history centre/about us/historyofhull.aspx [Accessed 5.5.2017].

(2) It is not yet clear whether the unemployment figures 2016 constitute an outlier. What seems to be clear is that a lot of the jobs which have recently been created in Hull are relatively insecure jobs in the so-called gig economy. Table 1 states the unemployment figures for 2015 because they are more typical for the level of unemployment in Hull in the last few decades.

\section{References}

AWI 2009. Konzeptstudie Klimastadt Bremerhaven. Bremerhaven: Alfred-Wegener-Institut.

Bertelsmann Stiftung 2017. Bremerhaven - Pendler - 2013-2015. http://www.wegweiserkommune.de/statistik/bremerhaven+pendler+2013-2015+tabelle [Accessed 15.5.2017].

Bulkeley, H. 2005. Reconfiguring environmental governance: Towards a politics of scales and network. Political Geographer, (24), 875-902.

Bulkeley, H. and Betsill, M. 2005. Rethinking sustainable cities: multilevel governance and the 'urban' politics of climate change. Environmental Politics, 14 (1), 42-63.

Bulkeley, H., Castán Broto, V. and Edwards, G. 2015. An Urban Politics of Climate Change. London: Routledge.

Burns, J.M. 1978. Leadership. New York: Harper \& Row.

Centre for Cities. 2014. Cities Outlook 2014. http://www.centreforcities.org/wpcontent/uploads/2014/01/14-01-27-Cities-Outlook-2014.pdf [Accessed 15.5.2017].

Dorsch, M.J. and Flachsland, C. 2017. A Polycentric Approach to Global Climate Governance. Global Environmental Politics, 17 (2), 45-64.

Gupta, J., and Grubb, M.J. eds. 2000. Climate Change and European Leadership: A Sustainable Role for Europe?. Dordrecht: Kluwer Publishers.

Homsy, G.C. and Warner, M.E. 2013. 'Cities and Sustainability: Polycentric Action and Multilevel Governance'. Urban Affairs Review, 49 (1), 1-28. 
Hooghe, L. (ed.) (1996) Multi-level Governance and European Integration, Oxford: Clarendon Press.

Hull City Council 2010. Kingston upon Hull Climate Change 2010-2020. Hull: One Hull.

Hull City Council 2013. Energy City. http://cityplanhull.co.uk/index.php/energy-city-2/ [Accessed 06.09.2016].

Hull Data Observatory 2017. Local economy overview (Hull).

http://109.228.11.121/IAS Live/profiles/profile?profileld=9 [Accessed 10.03.2018].

Hull UK City of Culture 2017. Somewhere becoming Sea. https://www.hull2017.co.uk/whatson/events/somewhere-becoming-sea/ [Accessed 24.05.2017].

Jänicke, M. 2014. Multi-level reinforcement in Climate Governance. In: A. Brunnengräber and M.R. Di Nucci eds. Im Hürdenlauf zur Enegiewende, Berlin: Springer, 35-47.

Jonas, A.E.G., Gibbs, D. and While, A. 2011. The New Urban Politics as a Politics of Carbon Control. Urban Studies 48, 2537-2544.

Jonas, A.E.G, Wurzel, R., Monaghan, M. and Osthorst, W. 2017. Climate change, the green economy and re-imagining the city. Die Erde, 148 (4), 197-211.

Jordan, A., Huitema, D. van Asselt, H. and Forster, J. eds. 2018. Governing Climate Change: Polycentricity in Action. Cambridge: Cambridge University Press.

Kaelble, H. 1988. Vers un societé européene, 1880-1990. Paris: Belin.

Kane, R.J. 2005. Compromised police legitimacy as a predictor of crime in structurally disadvantaged communities. Criminology, 43 (2), 462-498.

Kemmerzell, J. 2017. Überlokales Handeln in der lokalen Klimapolitik. In: M. Barbehön and S. Münch. eds. Variationen des Städtischen - Variationen lokaler Politik. Wiesbaden: Springer, 245-71.

Kern, K. and Bulkeley, H. 2009. Cities, Europeanization and Multi-level Governance, Journal of Common Markets Studies. 47 (1), 309-332.

Kythreotis, A.P. and Bristow, G.I. 2017. The 'resilience trap': exploring the practical utility of resilience for climate change adaptation in UK city-regions. Regional Studies, 51 (10), $1530-1541$.

Liefferink, D. and Wurzel, R.K.W., 2017. Environmental Leaders and Pioneers: Agents of Change. Journal of European Public Policy. 24 (7), 651-68. 
Magistrat 2017. Seestadt Bremerhaven. Statisticher Kurzbericht Dezember 2017. Bremerhaven: Magistrat der Stadt Bremerhaven.https://www.bremerhaven.de/sixcms/media.php/204/Statistischer+K urzbericht+Dezember+2017.pdf, [Accessed 5.3.2018].

Mederake, L. 2015. Opportunities for the Local Government of Bremerhaven Provided by the Project "Klimastadt Bremerhaven" in Times of Limited Municipal Room for Maneuvre. Bremen: Hochschule Bremen.

Migration Observatory 2014. Changes to the migrant population of Yorkshire and the Humber 2001-2011.

http://www.migrationobservatory.ox.ac.uk/press/changes-to-the-migrantpopulation-of-yorkshire-and-the-humber-2001-2011/ [Accessed 8.03.2018].

Mol, A. 2010. Environmental authorities and biofuel controversies. Environmental Politics, 19 (1), 61-79.

Morrison, T.H., Adger, W.N., Brown, K, Lemos, M.C., Huitema, D. and Hughes, T.P. 2017. Mitigation and adaptation in polycentric systems: sources of power in the pursuit of collective goals, WIREs Climate Change, 7, 1-16, doi: 10.1002/wcc.479.

Ostrom, E. 2009. A Polycentric Approach for Coping with Climate Change, Policy Research Working Paper 5095. Washington: The World Bank.

Ostrom, E. 2014. A Polycentric Approach for Coping With Climate Change. Annals of Economics and Finance, 15 (1), 97-134.

Porter, M. 1990. The Competitive Advantage of Nations, Harvard Business Review, March/April, 73-93.

Rowlands, I. 1995. The Politics of Global Atmospheric Change. Manchester: Manchester University Press.

SUBV 2010. Klimaschutz- und Energieprogramm 2020. Bremen: Der Senator für Umwelt, Bau und Verkehr (SUBV).

Schreurs, M. and Tiberghien, Y. 2007. Multi-level Reinforcement: Explaining European Union Leadership in Climate Change Mitigation. Global Environmental Politics, 7 (4), 19-46.

Statistisches Landesamt Bremen 2017. Zahlenspiegel. November 2017. https://www.statistik.bremen.de/detail.php?gsid=bremen65.c.2076.de

Strange, S. 1998. States and Markets. London: Pinter Publishers. 
While, A., Jonas, A.E.G. and Gibbs, D. 2010. From Sustainable Development to Carbon Control. Transactions Institute of British Geographers, 35 (1), 76-93.

Wilson, W.J. 1987. The Truly Disadvantaged. Chicago: University of Chicago Press.

Wurzel, R., Connelly, J. and Liefferink, D. eds. 2017. The European Union in International Climate Change Politics. London: Routledge. 